\title{
COMPARATIVE DIGESTIBILITY STUDIES WITH HENS AND RATS
}

\author{
LIISA SyrJÄLÄ \\ University of Helsinki, Department of Animal Husbandry
}

Received July 22, 1970

\begin{abstract}
Trials were made to compare the digestibility of feeds in hens and rats. In the comparison particular attention was paid to the true digestibility of the feeds. The digestibility of rusks made of wholewheat meal was compared in hens and rats. The rats digested $62.1 \%$ of the cell wall substances of the whole wheat meal, while the value for the hens was $16 \%$-units lower. The true digestibility of the other $\mathrm{N}$-free organic matter was also clearly lower in the hen trial than in the rat trial. In the rat trials the digestibility of wholewheat meal was compared with that of bark meal. The true digestibility of the organic matter of the bark meal was only $23.6 \%$, while that of the wholewheat meal was $92.4 \%$. The digestibility of the cell wall substances of the bark meal was $18.5 \%$ and of the wholewheat meal $62.1 \%$.
\end{abstract}

It is rather difficult to compare the digestibility of feeds in hens and rats, owing to the great differences in the digestive tract and excreta of these animals. If the comparison is based on the apparent digestibility values, the results can be deceptive. This is due to the fact that the quantity and quality of the endogenous and bacterial materials of faeces vary considerably in the different animal species, and also in the same species when different rations are given. With poultry the uric acid of the excreta also leads to inaccurate digestibility results, if these are based only on the apparent digestibility. If the efficiency of digestion in different animal species is to be compared, the true digestibility of the feeds of these animals has to be known. The same applies if widely differing feeds are given to the same animal species (SYRJÄLÄ 1967). In this paper the word faeces means also the excreta of the hens.

The purpose of this study was to investigate and compare the efficiency of digestion in hens and rats by estimating the true digestibility of their feeds. The feeds used in the digestibility trials were wholewheat meal and bark meal. The latter is made from the inner bark of pine.

\section{Experimental procedure}

F e eds. The digestibility of wholewheat meal was studied in hens and rats; the digestibility of bark meal only in rats. 
For the hen and rat experiments rusks containing $\mathrm{Cr}_{2} \mathrm{O}_{3}$ were made from wholewheat meal, according to the following recipe:

$\begin{array}{lrlr}\text { wholewheat meal } & 2 \mathrm{~kg} & \text { yeast } & 100 \mathrm{~g} \\ \mathrm{NaCl} & 20 \mathrm{~g} & \text { whole milk } & 1 \mathrm{l} \\ \text { sugar } & 200 \mathrm{~g} & \mathrm{Cr}_{2} \mathrm{O}_{3} & 8 \mathrm{~g}\end{array}$

$\mathrm{Cr}_{2} \mathrm{O}_{3}$, sugar and salt were first mixed together carefully, and then mixed thoroughly with the meal. After baking the bread was sliced and dried to rusks. These were ground for the hens and given whole to the rats.

The bark bread for the rats was made according to the following recipe:

$\begin{array}{lrlc}\text { bark meal } & 1 \mathrm{~kg} & \text { yeast } & 100 \mathrm{~g} \\ \text { white wheat flour } & 1 \mathrm{~m} & \text { whole milk } & 2.5 \mathrm{I} \\ \mathrm{NaCl} & 20 \mathrm{~g} & \mathrm{Cr}_{2} \mathrm{O} & 8 \mathrm{~g} \\ \text { sugar } & 200 \mathrm{~g} & & \end{array}$

Bark meal was made by drying and grinding inner pine bark. The bread was not dried. The rats received it fresh. The animals ate the bread almost greedily.

Trial with hens. Four healthy hens that had finished laying were used for the experiment. The hens were kept in the same $2 \times 2 \mathrm{~m}^{2}$ net-covered pen. Before the experiment the animals were accustomed to the new conditions on normal feeding. During the experiment they were fed twice a day. Chicken lime and water were given ad libitum. The faeces were collected twice a day. They were each time collected very carefully so that the proportion of the caecum and other excreta in the samples remained correct. The animals were given the experimental feed for 8 days, but the analyses were made only from the faeces excreted in the last two days.

Trials with rats. The experimental procedures in the wholewheat meal and bark meal trials were the same. Four rats of the same sex were used in both trials. They were kept in the same cage. The rats were weighed at the beginning and end of the trial. They had food and water ad libitum during the day-time and water at night. In the evening the rats were brushed lightly and moved to two net cages, under which was another closer net for the collection of faeces. Only the faeces excreted in the night, which were free from hair and food, were used for the analyses. Both digestibility trials lasted 9 days, but faeces were collected only in the last 5 days. In both trials the average weights of the rats decreased: $17 \mathrm{~g}$ when the animals were fed with wholewheat meal rusks and $22 \mathrm{~g}$ with bark bread.

A nalytic a $1 \mathrm{meth}$ ods. From the meals and ground rusks determinations were made of dry matter, ash and crude protein. Plant cell wall substances were also determined by the methods of SAlo (1965 a) and PALOHEImo and VAINio (1965), and $\mathrm{Cr}_{2} \mathrm{O}_{3}$ from the rusks (Palohermo and Palohermo 1935).

Most of the stones were removed from the faeces of the hens before the analyses. All the analyses were made from fresh faeces samples. The faeces of the rats were very dry, their dry matter content being $60 \%$. They were prepared for the analyses by pounding in a porcelain mortar with two parts of water to one part of faeces.

From the faeces samples determinations were made of dry matter, ash, $\mathrm{Cr}_{2} \mathrm{O}_{3}$, crude protein and plant cell wall complex. The last-mentioned was determined from the faeces samples in the wholewheat meal trials of the hens and rats by the "sinter method" and 
in the bark meal trial of the rats by the mincubation method». Both methods have been developed by Palohermo and SyrJälä, but are still unpublished. In the sinter method (Pulliainen, Paloheimo and Syrjälä, 1968 p. 8) the faecal exogenous material is separated from the faecal endogenous and bacterial material (PALOHEIMo 1962, PALOheimo 1966, PAlohermo, SyrJäLÄ and Vainio 1968) by ultrasonic treatment and sinter filtration. In the incubation method the faecal endogenous and bacterial material is dispersed with the aid of enzymes derived from the faecal bacteria by incubating a suspension of the faeces for about 20 hours at $40^{\circ} \mathrm{C}$. The method also involves washing and sedimentation. The incubation method was used instead of the sinter method in the bark meal trial with the rats, because the faeces contained a large proportion of mucus, which disturbed the sinter filtration. The cell wall complex is obtained in both methods from a certain crude fraction ( $\mathrm{F}$-fraction) by extraction with $80 \%(\mathrm{v} / \mathrm{v})$ ethanol and using ash and crude protein corrections.

\section{Results}

Table 1 shows the chemical composition of the wholewheat meal, the bark meal and the faeces samples, and their digestibility values. Table 2 shows the amounts of the digestible nutrients per $100 \mathrm{~g}$ of dry matter of meals. In calculating the digestibility percentages of the meals it was supposed that all the indigestible materials in the rusk and bread were derived from the wholewheat and bark meal. This supposition is not quite correct, however, because $36.5 \%$ of the bark bread dry matter consisted of white wheat flour. However, since only $3.7 \%$ of the white flour consisted of cell wall substances, the major part of it being composed of more easily digestible cell enclosure substances, the error caused by this supposition cannot be great. The negative apparent digestibility of the dry matter of the bark meal, $1.3 \%$, shows, however, that the indigestible dry matter of the faeces was derived from other constituents of the bark bread besides the bark meal.

In compiling the four columns in the right-hand part of the tables, it was supposed that the exogenous organic matter of the faeces equals the organic matter of the F-fraction. This being so, the exogenous crude protein of the faeces equals the crude protein of the $\mathrm{F}$-fraction. Further, the exogenous $\mathrm{N}$-free organic cell enclosure substances equal the exogenous $\mathrm{N}$-free organic matter minus the cell wall complex.

The digestibility values in the left-hand part of the tables show the apparent digestibility of the feeds, with the exception of the values of the cell wall complex, which are true. The values in the right-hand part show the true digestibility.

\section{Discussion}

When comparing the digestibility values of the whole-wheat meal trials with the hens and rats, it is advisable to consider only the values which do not include ash or crude protein. Hen excreta contain small stones and sand which are not derived from the food and these remain in the ash after incineration. The ash also contains minerals excreted through the kidneys. In addition, hen excreta contain uric acid, which accounts for the values for crude protein being too high. Another factor which makes the figures for crude 

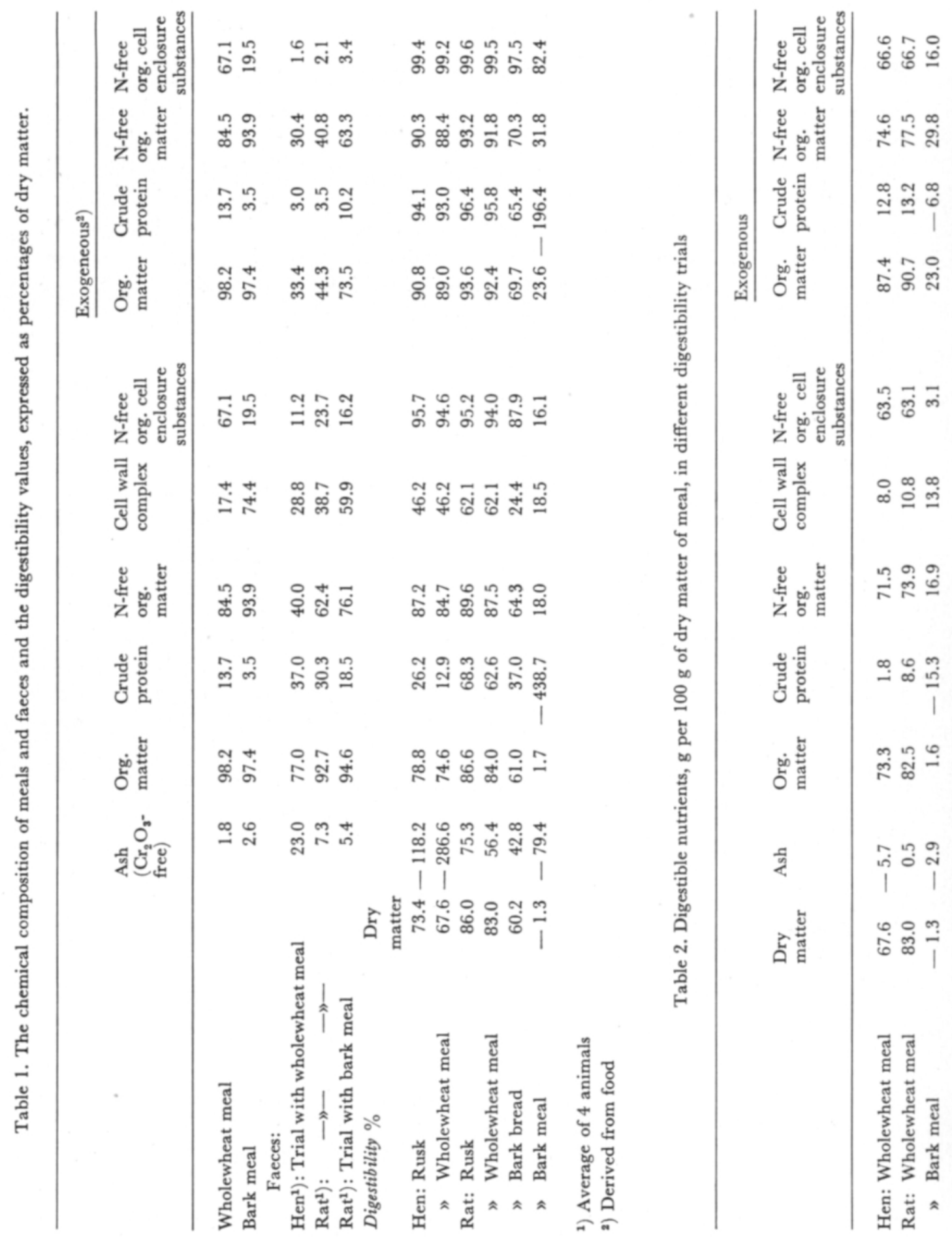
protein excessive is the high $\mathrm{N}$ content of the uric acid, which is $33.3 \%$. This means that the $\mathrm{N}$ content of the crude protein is over $16 \%$ and that the coefficient of 6.25 , used in calculating the crude protein, is consequently too high.

The plant cell wall complex fraction of the faeces determined by the sinter method is relatively free from endogenous material, including uric acid. The values of the cell wall complex are also protein-corrected and ash-free. It can thus be seen that only the values for plant cell wall substances and the other figures showing the true digestibility can be used when comparing the efficiency of digestion in hens and rats.

Table 1 shows that the digestibility of the cell wall substances of the wholewheat meal is $16 \%$-units higher in the rats than in the hens. In the case of the exogenous organic and the $\mathrm{N}$-free organic matter, the values are about $3 \%$-units higher in the rats, while the digestibility values of the exogenous $\mathrm{N}$-free organic cell enclosure substances are about same in both species and very high, about $99 \%$. When the hens consume $100 \mathrm{~g}$ of the dry matter of the rusks, they loose $11.6 \mathrm{~g}$ of organic matter in the endogenous fraction of the faeces. The corresponding figures for the rats is $6.8 \mathrm{~g}$.

A comparison of the digestibility of the wholewheat meal and the bark meal in the rats shows that they digested $62.1 \%$ of the former and only $24.4 \%$ of the latter. This is due to differences in the composition of the cell wall substance fraction (SALO 1965 b, SAlo and Kotilainen 1969), which are shown as percentages in the following tabulation:

$\begin{array}{lcc} & \text { in whole wheat meal } & \text { in bark meal } \\ \text { cellulose } & 8.6 & 35.4 \\ \text { hemicellulose } & 47.1 & 31.3 \\ \text { crude lignin } & 9.2 & 18.8 \\ \text { other cell wall substances } & 35.1 & 14.5\end{array}$

The value for the mother cell wall substances» is calculated by subtracting from the cell wall complex determined by the method of PALOHEImo and Vainio (1965) the fractions of the cellulose, hemicellulose and crude lignin (SALO 1965a). The remaining fraction includes uronic acid anhydrides. The value can be calculated in this way because the cell wall substance fractions determined by the methods of Paloheimo and Vainio and of Salo do not differ very much from each other. Lignin, which is practically indigestible, protects other cell wall substances and cell enclosure substances against the digestive enzymes. This is probably why the digestibility of the exogenous $\mathrm{N}$-free organic cell enclosure substances is $99.5 \%$ in the wholewheat meal, and only $82.5 \%$ in the bark. It also explains why the digestibility of the exogenous organic matter is high, $92.4 \%$, in the wholewheat meal, and low, $23.6 \%$, in the bark meal.

It may seem surprising that the digestibility value of the exogenous crude protein of the bark meal is negative. This is apparently partly due to the protective effect of the cell wall constituents, but also to the fact that a part of the correction for protein made to the cell wall fraction relates to endogenous and $\mathrm{N}$-rich mucus, which was very abundant in the faeces obtained in the bark meal trials. When the rats consumed $100 \mathrm{~g}$ of the dry matter of bark bread they lost $8.4 \mathrm{~g}$ of endogenous organic matter, while in the case of the rusks made of wholewheat meal the corresponding loss was $6.8 \mathrm{~g}$.

The chemical composition of bark meal made from the inner bark of pine is different from that of pine wood (Salo 1965b, Salo and Kotilainen 1969). 
The following tabulation shows the percentage composition of the dry matter of bark meal and pine wood.

$\begin{array}{lcc} & \text { in bark meal } & \text { in pine wood } \\ \text { ash } & 2.6 & 0.2 \\ \text { crude protein } & 3.5 & 0.6 \\ \text { crude lignin } & 14.0 & 25.1 \\ \text { cellulose } & 26.3 & 39.6 \\ \text { hemicellulose } & 23.3 & 14.7 \\ \text { other cell wall substances } & 30.3 & 19.8\end{array}$

The percentages of the different sugar anhydrides in the hemicellulose fraction are as follows:

$\begin{array}{lcc} & \text { in bark meal } & \text { in pine wood } \\ \text { mannose } & 0 & 40 \\ \text { xylose } & 15 & 30 \\ \text { arabinose } & 45 & 10 \\ \text { glucose } & 20 & 10 \\ \text { galactose } & 20 & 10\end{array}$

The above figures show that pine wood contains much larger amounts of poorly digestible crude lignin and xylose anhydrides (SALO 1965a) than bark meal, while the more easily digestible arabinose, glucose and galactose anhydrides constitute $85 \%$ of the hemicellulose of bark meal. In pine wood the corresponding percentage is only 30 . This probably explains why man is able to utilize bread made of bark. TigerstedT (1919) has shown that the apparent digestibility of dry matter in man is $9.3 \%$.

A c k n o w le d g e men t s. I wish to express my thanks to Professor emeritus Lauri Paloheimo for his valuable advice during the work, and to Miss Pirkko Myllykangas, B. Agr., for the technical assistance.

\section{REFERENCES}

PALонеiмo, L. 1952. Food analysis and the evaluation of foods. Nordisk jordbruksforskning 44: 78 - 86. - - 1966. Some remarks on the digestion trials. World Rev. Anim. Prod. 2: 86-91.

Palohemo, L. \& Paloheimo, I. 1935. Eine photometrische Methode zur Bestimmung der $\mathrm{Cr}_{2} \mathrm{O}_{3}$ bei Verdaulichkeitsuntersuchungen nach sog. quantitativen Indikatorverfahren. Tierernäh. 7:317342.

Palohermo, L. \& Vainio, K. A. 1965. Determination of the complex of cell wall substances in plant products. J. Scient. Agric. Soc. Finn. 37: 305-312.

Palohemo, L., Syrjälä, Lisa \& Vainio, K. A. 1968. Studies on the faeces. J. Scient. Agric. Soc. Finn. 40: $237-2461$.

Pulliainen, E., Palohermo, L. \& SyrjäLÄ, Lisa. 1968. Digestibility of blueberry stems (Vaccinium myrtillus) and cowberries (Vaccinium vitis-idea) in the willow grouse (Lagopus lapogus). Annales Academiae Scientarum Fennicae Series A. IV. Biologica 126: 1-14.

SALO, M.-L. 1965a. Determination of carbohydrate fractions in animal foods and faeces. Acta Agr. Fenn. 105: 1-102.

$-»-1965 \mathrm{~b}$. On the content of cell-wall constituents in various plant materials. J. Scient. Agric. Soc. Fenn. 37: 127-134.

Salo, M.-L. \& Kotilainen, K. 1969. On the carbohydrate composition and nutritive value of some cereals. J. Scient. Agric. Soc. Finn. 42: 21-29. 
SYRJÄLÄ, LnsA. 1967. Kettoaineiden kokonaispaljouden määrittäminen rehuista ja sonnasta sekä sulavuus eri eläinlajeilla. Lisensiaattityö. Helsingin yliopiston kotieläintieteen laitos. Helsinki.

Tigerstedt, C. 1919. Über den Nährwert der Fichtenbaumrinde beim Menschen. Öfversigt af Finska Vet.-Soc. Förh. LXI, 16: 1-26.

\title{
RUOANSULATUKSEN VERTAILUA KANOILLA JA ROTILLA
}

\author{
Lisa SYrJäLX
}

\section{Helsingin yliopiston kotieläintieteen laitos}

Selostetuilla kokeilla verrattiin kanojen ja rottien ruoansulatuskyvyn tehokkuutta. Sulavuuksia verrattaessa kiinnitettiin huomiota rehun todelliseen sulavuuteen.

Kanoilla ja rotilla oli vertailun kohteena sama kokojyvävehnäjauhosta valmistettu korppu. Rotat sulattivat kokojyvävehnäjauhon kettoaineesta $62.1 \%$, kun taas kanat $16 \%$-yksikköä vähemmän. Myöskin muiden typettömien orgaanisten aineiden todellinen sulavuus oli kanakokeissa selvästi alhaisempi kuin rottakokeissa.

Rottakokeilla verrattiin toisiinsa kokojyvävehnäjauhon ja pettujauhon sulavuutta. Etupäässä näiden aineiden erilaisesta ligniinipitoisuudesta johtui, että pettujauhon orgaanisen aineen todellinen sulavuus oli vain $23.6 \%$, kun taas kokojyvävehnäjauholla se oli $92.4 \%$. Kettoaineiden sulavuus edellisessä tapauksessa oli $18.5 \%$ ja jälkimmäisessä $62.1 \%$. 